\title{
INTRODUCTION
}

\section{RELIGION IN ANCIENT GREECE AND ROME: CONTACTS, ENCOUNTERS AND EXCHANGES ${ }^{1}$}

The fragmentary and varied nature of the Mediterranean was perceived by scholars who dedicated to the study of this region. The revolutionary ideas of Fernand Braudel's ground-breaking work, The Mediterranean and the Mediterranean World in the Age of Philip II (1975), shifted the focus on Mediterranean space from its continental boundaries to its marine basin, and reoriented historical inquiries in the region from politics to culture and economy. After Braudel, it took many years for Mediterranean-wide studies to emerge as a trend in modern scholarship. The next significant contribution was made by Peregrine Horden and Nicholas Purcell, with their publication, The Corrupting Sea: A Study of Mediterranean History (2001), which traced common themes underlying over 3,000 years of history in the Mediterranean. The authors explored the region's extreme fragmentation into various land- and seascapes, producing a novel analysis of the relationships between differing microecologies. They notably demonstrated the influence of uncertainty on the region's microcosms, in the timing and amount of rainfall, the direction and intensity of wind, and the possibility of volcanic and seismic catastrophe. But if the Mediterranean was an area of uncertainty, it was also a place of great mobility, with an incalculable number of islands and the most extensive costal area of the planet. That its navigators rarely lost sight of land and the sun illuminated it year round made the Mediterranean a land of opportunity, which encouraged people to diversify, produce and explore.

\footnotetext{
1 We would like to thank to Renata Garraffoni (Federal University of Paraná) for inviting us to organise this volume and to Priscila Vieira (Federal University of Paraná), who is charge of the Revista História: Questões $\&$ Debates, for assisting us in all the stages of the production of this dossier. We are mostly indebted to Yannos Kourayos who kindly gave to us a photo from the recent restored building A at the sanctuary of Despotiko which is used as the cover photo of this volume. We extend our thanks to Andrew Gipe Lazarou (Diakron Institute) who produced the cover of this volume and who made the English editing of this introduction. Any errors that may remain is our responsibility. This dossier also encompasses a section on Brazilian history with three articles. For further information see the introduction in Portuguese written by Priscila Vieira.
} 
The connecting power of the sea is explored in another monumental book written in the $21^{\text {st }}$ Century, titled The Making of the Middle Sea (2014). Using the vast amount of archaeological data available in this region, its author, Cyprian Broodbank, unpacks the region's history from 1,8 million years ago to the Classical period, demonstrating how the easily-navigable, ecologically-fragmented world of the Mediterranean evolved into an oecumene through the agency of inhabitants on its islands and shores.

The fragmentary nature of the Mediterranean region is one of its most distinctive characteristics, acting as a historical stimulus for the formation of complex transportation networks, which have connected places of various scale and significance, from the family farm to imperial states, and have involved all manner of players, from the merchant to the prince (MALKIN; CONSTANTAKOPOULOU; PANAGOPOULOU, 2011). The Mediterranean has enabled the movement of countless multitudes around its vast area, not only because of the proximity of its coastal sites and islands, but also because of its broadly-compatible climatic conditions (i.e. a semiarid summer and wet winter) which facilitated the dissemination of products and skills (e.g. crops, perfumes, vase-making, and seafaring techniques) (BROODBANK, 2014). The extensive circulation of people and goods in the Mediterranean is also reflected in the nature of the region's religious practices. Objects originating from around the ancient world were presented as offerings in tombs and sanctuaries throughout the Mediterranean region. And religious practices were transmitted during different cycles of upheaval and migration, which involved areas in close proximity and at great distances across the terraqueous network.

The present dossier presents several case studies about cultural diversity and religious exchanges in the Greco-Roman world by focusing on the relationships between various fragments of the Mediterranean region (MALKIN, 2011). It includes nine papers in multiple subject areas; the first five in the field of Classical Archaeology, and the following four in History and Literature. The contributions (made in Portuguese, English and French) come from scholars working on different aspects of religion in the GrecoRoman world. The dossier begins its investigation of exchanges and cultic practices at the heart of the Cyclades, which hosted one of the most important archaeological discoveries made in Greece in the past 10 years. Yannos Kourayos and Kornilia Daifa, overseers of the excavations at Despotiko, give an overview of this important Cycladic sanctuary, which is known only from archaeological evidence. Located at the centre of the Cyclades, at a connective 
node of the archipelago, this sanctuary was erected by the powerful island of Paros, and has revealed a multitude of votives originating from various regions of the Cyclades and more distant parts of the Mediterranean. The second paper of this volume, written by Elena Korka and several members of her team, presents some of the recent results of excavations at Tenea, around the village of Chiliomodi in Corinth, a site whose material culture and cycle of myths are linked with the Trojan War. After presenting a summary of the work conducted so far, Korka discusses the main deity worshiped at Tenea (the god Apollo) and the found artefacts which shed further light on his ancient cult following. A number of the ancient objects included in these accounts will be published for the first time in this paper. The next paper, written by Michael Fowler of East Tennessee State University, examines the four Late Archaic tumular monuments in the Northern Necropolis of the Pontic Greek settlement of Istros. It explores several features of these burials which are comparable to heroic cremation burials as described in epic poetry (particularly the funeral of Patroklos in Homer's Iliad) and discusses the striking possibility of human sacrifice. In addition to unusual religious habits amongst Greeks and reconsiderations of Pyre A at Orthi Petra (Eleutherna, Crete), this paper also discusses a site on the Black Sea, a region that remains understudied outside Russian scholarly circles. From the Black Sea, our dossier moves to the shores of the Corinthian Gulf. Dora Katsonopoulou, Director at the excavations at Helike, discusses the cult of Poseidon Helikonios with emphasis on the ancient ancestral altars of the Ionic race. She also examines the establishment of the cult of Poseidon Helikonios, brought by the Achaeans to the coast of Asia Minor, then transmitted to the Black Sea region. The next paper, written by Lilian Laky of the University of São Paulo, discusses the interconnectivity of the Mediterranean by examining the iconography of coins with images of eagles and thunderbolts (the attributes of Zeus). The author uses coins minted by Crotone (Magna Grecia) and Olympia (Peloponnese) to discuss the spreading of the cult epithet of Zeus Olympios. In addition to illuminating the relationship between Olympia and Sicily, the paper also makes an important contribution to scholarship about the regional dissemination of local epithets, an underexplored topic which is slowly gaining the attention required for its explanation.

The next four papers of this dossier will examine connections and exchanges among Ancient Greek and Roman religions through the lens of Ancient History and Literature. The section opens with a paper by Pierre Ellinger (Université de Paris), who analyses Greek myths (especially the legends of Taurian Artemis, as portrayed in Euripidean tragedy) concerning 
the abductions of divine statues from seaside sanctuaries. The paper explores the maritime dimension of a number of ancient tales, focusing on seafaring routes and their articulation around particular nodes, the experience of departure and landing, and the context in which these stories would have been told. By emphasizing the maritime dimension of these tales, the author subverts our familiarity with Greek space, reorienting our perspective from the landscape of the city to the seascape along its margins. The paper, therefore, not only sheds light on the enigmatic cult of the Taurian Artemis, whose worship continues to elude and intrigue modern scholars, but also presents an important contribution to emerging studies on maritime religions.

The next paper, presented by Lucio Maria Valletta of the École Pratique des Hautes Études, discusses cults in the Black Sea region. The author examines a passage of Herodotus about the Scythian people to reflect on the existence of cultural elements, held by peoples that lived and moved in the surrounding regions of the Mediterranean basin, including the Black Sea. The dossier continues with a paper by Júlia Avellar, of the Federal University of Uberlândia, which discusses Roman cults and religious festivals of the early Empire through the work of the Roman poet Ovid. Avelar examines the intersections between private cults and public festivals in ancient Rome. The author demonstrates that the religious cults in Ovidian poetry are poetic recreations which, through religious elements, provoke reflections about relationships of power in Antiquity. Returning to the Cyclades and Paros, the last paper of this volume, written by Rafael Silva and Teodoro Rennó Assunção of the Federal Univerity of Minas Gerais, departs from the dithyrambic fragments attributed to Archilochus (fr. $120 \mathrm{~W}$, fr. 96 Lasserre) and develops considerations about the relationship between the cult of Dionysus and the dissemination of the dithyramb.

Together the papers presented in this volume shed light on the richness and complexities involving religious exchanges in the Mediterranean and the Greco-Roman world. While some make important contributions by presenting original archaeological research about strategic socio-political regions, others present authentic theoretical frameworks to explain the complexities of cultural exchange observed by the dissemination of institutional coinage and vernacular myths.

Erica Angliker (Institute of Classical Studies, University of London). Lorena Lopes da Costa (Federal University of Western Pará). 
BRAUDEL, Fernand. The Mediterranean and the Mediterranean World in the Age of Philip II, vols. I-II. (transl. from the French by Siân Reynolds). New York, Evanston Harper \& Row, 1975.

BROODBANK, Cyprian. The Making of the Middle Sea: A History of the Mediterranean. London, Thames \& Hudson, 2014.

HORDEN, Peregrine and Nicholas Purcell. The Corrupting Sea. A study of Mediterranean History. Oxford, Blackwell Publishers, 2001.

KNAPPETT, Carl. Network Analysis in Archaeology. New Approaches to Regional Interaction. Oxford, Oxford University Press, 2013.

MALKIN, Irad. A Small Greek World. Networks in the Ancient Mediterranean. Oxford, Oxford University Press, 2011.

MALKIN, Irad, Christy Constantakopoulou and Katerina Panagopoulou (eds.). Greek and Roman networks in the Mediterranean. London, Routledge, 2011. 